\title{
Robotic Transanal Surgery. Initial Experience in a Developing Country
}

\section{Cirugía Robótica Transanal. Experiencia inicial en un País en Vías de Desarrollo}

\author{
Montserrat Guraieb-Trueba ${ }^{1}$ Juan Carlos Sánchez-Robles ${ }^{2}$ Eduardo Navarro-Lara ${ }^{3}$ \\ Víctor Javier Herrera-Virrueta ${ }^{1}$ \\ ${ }^{1}$ Colorectal Surgery Department, Hospital Central Militar, CdMx, \\ México \\ ${ }^{2}$ Colorectal Surgery Department, Hospital San Ángel Inn, CdMx, \\ Address for correspondence Montserrat Guraieb Trueba, MD, Blvd. \\ México \\ Adolfo López Mateos s/n., Miguel Hidalgo, CdMx, México \\ ${ }^{3}$ Colorectal Surgery Department, Hospital Ángeles del Carmen, \\ Guadalajara, Jal, México \\ J Coloproctol 2021;41(2):163-167.
}
Abstract
Keywords
- transanal surgery
- robotic surgery
- rectal cancer
- minimally invasive
- rectal polyps
- TAMIS
- R-TAMIS

Background Transanal minimally invasive surgery (TAMIS) is a surgical technique used for the excision of rectal neoplasia that gained popularity during the last decade. Due to the technical difficulty (non-articulated instruments, reduced workspace) and the long learning curve associated with this technique, the use of robotic platforms to improve resection results has been suggested and reported, at the same time that the learning curve decreases and the procedure is facilitated

Materials and Methods From March 2017 to December 2019, all patients with rectal lesions eligible for TAMIS were offered the possibility to receive a robotic TAMIS (RTAMIS). We used a transanal GelPoint Path (Applied Medical Inc., Santa Margarita, CA, USA) in the anal canal to be able to do the Da Vinci Si (Intuitive Surgical, Sunnyvale, CA, USA) robotic platform docking, which we used to perform the excision of the rectal lesion as well as the resection site defect.

Results Five patients between 34 and 79 years of age underwent R-TAMIS. The mean distance to the anal verge was $8.8 \mathrm{~cm}$. There were no conversions. The mean surgery time was 85 minutes, and the mean docking time was 6.6 minutes.

Conclusions Robotic TAMIS is a feasible alternative to TAMIS, with a faster learning curve for experienced surgeons in transanal surgery and better ergonomics. Further studies are needed to assess the cost-benefit relationship. received

July 13,2020

accepted

January 15, 2021

published online

May 24, 2021
DOI https://doi.org/

$10.1055 / \mathrm{s}-0041-1726051$.

ISSN 2237-9363. (c) 2021. Sociedade Brasileira de Coloproctologia. All rights reserved.

This is an open access article published by Thieme under the terms of the Creative Commons Attribution-NonDerivative-NonCommercial-License, permitting copying and reproduction so long as the original work is given appropriate credit. Contents may not be used for commercial purposes, or adapted, remixed, transformed or built upon. (https://creativecommons.org/ licenses/by-nc-nd/4.0/)

Thieme Revinter Publicações Ltda., Rua do Matoso 170, Rio de Janeiro, RJ, CEP 20270-135, Brazil 


\section{Resumo}

Palavras-chave
- cirurgia transanal
- cirurgia robótica
- câncer retal
- invasão mínima
- pólipos do reto
- TAMIS
- R-TAMIS

Introdução A cirurgia transanal minimamente invasiva (TAMIS, na sigla em inglês) é uma técnica que se tornou popular na última década para a excisão local de neoplasias no reto. Devido à dificuldade técnica (instrumentos não articulados, espaço de trabalho reduzido) e à longa curva de aprendizado representada por essa técnica, o uso de plataformas robóticas para melhorar os resultados da ressecção tem sido sugerido e relatado, ao mesmo tempo em que a curva de aprendizado diminui e o procedimento é facilitado.

Materiais e Métodos De março de 2017 a dezembro de 2019, foi oferecida aos pacientes com lesões retais candidatos ao TAMIS a possibilidade de ressecção transanal robótica (R-TAMIS). Foi utilizada uma porta de acesso transanal GelPoint Path (Applied Medical Inc. Santa Margarita, CA, EUA), que foi introduzida no canal anal para posteriormente criar pneumoperitônio e realizar o acoplamento do sistema robótico Da Vinci Si (Intuitive Surgical, Sunnyvale, CA, EUA) para realizar a ressecção e o fechamento do defeito por robótica.

Resultados Cinco pacientes entre 79 e 34 anos foram submetidos à R-TAMIS. A distância média à margem anal foi de $8,8 \mathrm{~cm}$. Não houve conversões. $O$ tempo cirúrgico médio foi de 85 minutos, e o tempo médio de acoplamento foi de 6,6 minutos.

Conclusões A R-TAMIS é uma alternativa à TAMIS convencional, com menor curva de aprendizado para cirurgiões experientes em cirurgia transanal minimamente invasiva e melhor ergonomia para ressecção e fechamento. Outros estudos são necessários para avaliar a relação custo-benefício.

\section{Introduction}

Total mesorectal excision (TME) is the treatment of choice for rectal cancer and is curative for $93 \%$ of the patients with stage I rectal cancer. Due to the high perioperative mortality and adverse events related to TME, transanal minimally invasive approaches have been developed for the management of benign and malignant rectal neoplasias. ${ }^{1}$

In 1983, in Germany, Dr. Gerhard Bues designed the platform and described the technique of transanal endoscopic microsurgery (TEM) to improve visibility and reach within the rectal lumen,. This platform helped him achieve en bloc resections of big rectal polyps as well as early rectal cancers. $^{2}$ In 1989, during the Clinical Congress of the Society of American Gastrointestinal and Endoscopic Surgeons (SAGES), Drs. Perissat and Mouret presented the first laparoscopic cholecystectomy, a procedure that was rapidly accepted and replicated among surgeons around the world, and a few years later was recognized as the standard approach for gallbladder disease as well as many other abdominal pathologies. ${ }^{3}$ With the rapid growth and acceptance of laparoscopy, the surgeons keep looking to decrease tissue trauma during many abdominal procedures, and it was in 2007 that Curcillo took surgery to a different level and performed the first colectomy with a single incision laparoscopic surgery (SILS) technique. ${ }^{2}$ Besides these advances, in India, during 2003, Dr. Rao et al. started to perform natural orifice transluminal endoscopic surgery (NOTES) using flexible endoscopes across the stomach to perform appendectomies. ${ }^{4}$ Transanal minimally invasive surgery (TAMIS), a hybrid technique between TEM and SILS, was described and popularized in
2010 by Dr. Atallah et al. They developed a cost-effective technique for the resection of rectal polyps. This approach has also proved to have a less stiff learning curve when compared with TEM. ${ }^{5}$

When conventional transanal excision is compared with TEM, the latter, has a significant improvement in resection quality, local recurrence rates and overall survival; specially in patients with Stage I rectal cancer. The use of TEM for rectal tumor excision, has proven to be a safe and effective alternative; with a similar morbidity and mortality when compared with conventional transanal excision. Nonetheless, although TEM was described more than 20 years ago, its use was not very popular among colorectal surgeons; this was probably because the procedure has a stiff learning curve, but also, because special equipment is necessary to perform it, which significantly increases the cost. ${ }^{2}$

Transanal minimally invasive surgery is a novel surgical technique, described to perform local excision of benign and malignant rectal neoplasia, that gained popularity in the early 2010̀s. This platform uses conventional laparoscopic instruments to achieve high quality local excisions. ${ }^{5,6}$ This innovative technique is a hybrid approach between the TEM and SILS; approaches that have in common the working angles, hence, the surgeon needs a similar set of skills to perform either one of these procedures. Nevertheless, as mentioned before, to perform TEM the surgeon will need a special set of instruments, disadvantage that has contributed to his low popularity. ${ }^{2}$

When conventional transanal excision is compared with TEM and TAMIS, we found that the with the latter the surgeon can reach lesions that are higher in the rectum, as 

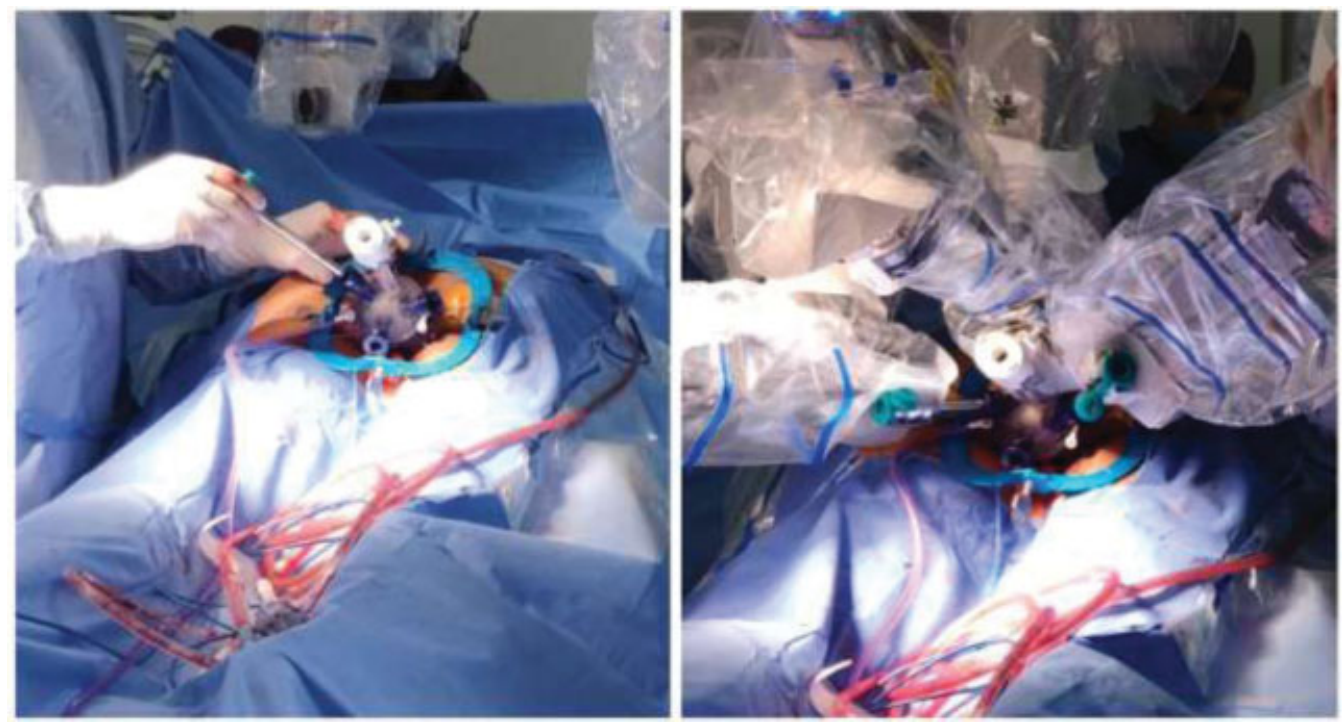

Fig. 1 Transanal docking.

well as have the ability to obtain en bloc resection with better margins, hence lower local recurrence rates. ${ }^{1,7,8}$

In the task to obtain better results, surgeons around the world have been developing and utilizing existent technologies for TAMIS; the use of robotic platforms to perform transanal surgery is yet to be approved however small series have shown promising results. Due to its proven improvement in surgeoǹs ergonomics, several authors have proposed natural orifice surgery using the robotic platforms da Vinci Si and Xi (Intuitive Surgical, Sunnyvale, CA, USA). ${ }^{1,9,10}$ In 2011, Atallah et al published the first experience with this technique; they utilized 18 cadaveric models to successfully perform a variety of transanal procedures (polyp excision, TME and rectal fistulae). ${ }^{11}$ Afterwards, in 2018, Tomassi et al., published a case series of 58 consecutive patients subjected to benign and malignant rectal neoplasia thru robotic transanal surgery (R-TAMIS), confirming that this is a feasible alternative to transanal approaches. ${ }^{1}$

The robotic approach in TAMIS is the latest evolution of natural orifice surgery for the treatment of rectal neoplasia. Despite the fact that some case series have been published worldwide, this paper presents the initial experience with $\mathrm{R}$ TAMIS in Mexico and the results of our first consecutive 5 cases.

\section{Methods}

Over a 33-month period (March 2017-December 2019), all patients with rectal lesions who were candidates for conventional transanal excision were offered the option to undergo R-TAMIS resection. Informed consent was obtained from each patient, and each was given the option to undergo conventional transanal excision, TAMIS or R-TAMIS. Patients with locally advanced rectal cancer were not considered candidates for conventional local excision or TAMIS/RTAMIS. Patients with biopsy-proven malignant lesions were excluded from the study. Postoperatively, patients were followed for a mean of 22.6 months (6-39 months).

To perform R-TAMIS, patient was placed either in prone or supine position depending on lesion location within the rectal wall. We used a Lone Star (Cooper Surgical Inc. Trumbull, CT, USA) retractor, after its placement, a transanal access port GelPoint Path (Applied Medical Inc. Santa Margarita, CA, USA) was first lubricated and then gently introduced to the anal canal. Once in position, we gained access to the rectal vault and pneumorectum was established. Da Vinci Si (Intuitive Surgical, Sunnyvale, CA, USA) system docking was made (-Fig. 1). Robotic resection and defect closure with a continuous running suture with a barbed suture was performed (-Fig. 2).

Every patient received mechanical bowel prep plus oral antibiotics (neomycin/metronidazole) and a prophylactic dose of IV Metronidazole and a second-generation Cephalosporin 30 minute before the beginning of the procedure.

\section{Results}

Five patients aged 79 to 34 years old (mean 56.2) underwent R-TAMIS resection of rectal lesions ( - Table $\mathbf{1}$ ). The average distance from the anal verge was $8.8 \mathrm{~cm}$. Histopathologic examination reported: one early adenocarcinoma (T1) (case B); two tubulovillous adenomas of whom one had low grade dysplasia (case $\mathrm{C}$ ) while the other one had no dysplasia (case D). Also, a tubular adenoma with low grade dysplasia (case A) was reported and a case of deep cystic colitis in a patient with history of HIV with adequate medical control with HARRT (case E). All resection margins were negative. No conversions from R-TAMIS to TAMIS or conventional surgery are reported.

As shown in -Table 2, four out of the five patients were discharged on postoperative day 1 . The exception was case A, who presented with a lesion at the rectosigmoid junction and during the procedure we needed to enter the peritoneal cavity. The patient stayed for postoperative surveillance and was discharged with no complications. Of the 5 patients subjected to R-TAMIS, case B presented local recurrence at the 3-month follow-up. The patient underwent laparoscopic TME and is currently disease-free. No other patient presented recurrence during the follow-up (mean 22.6 months). 

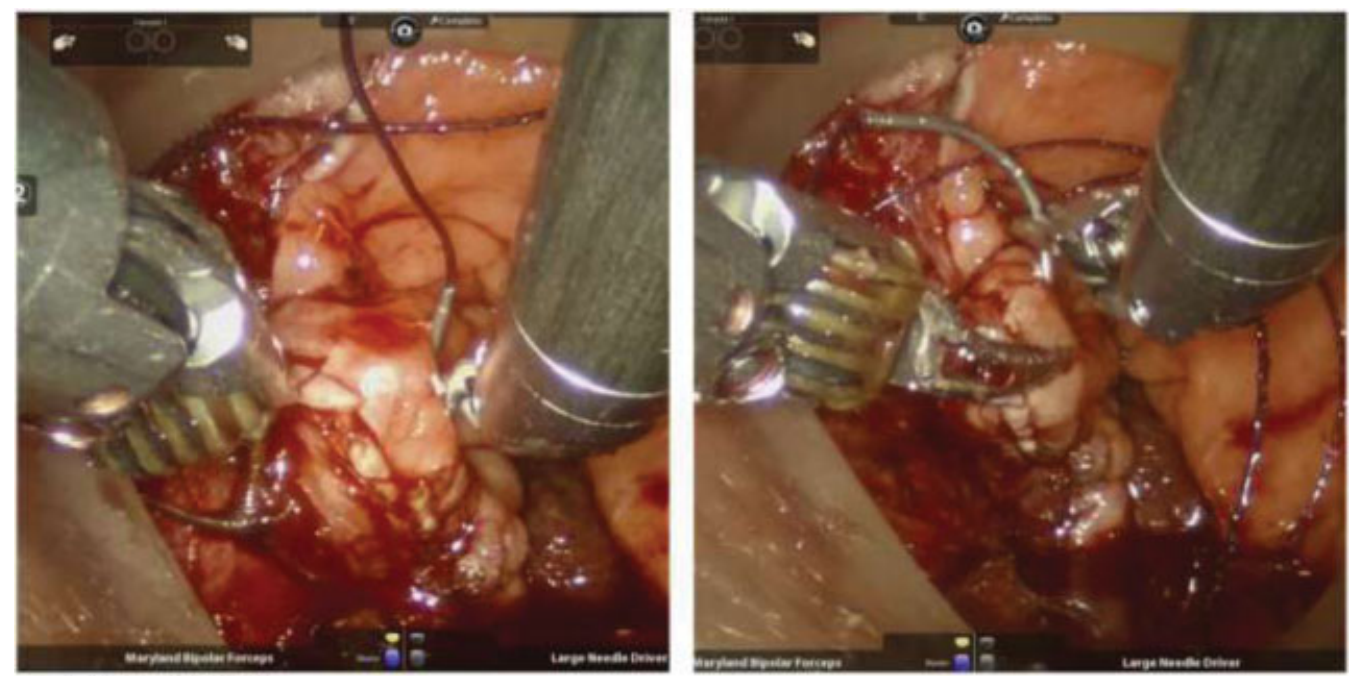

Fig. 2 Robotic defect closure.

Table 1 Demographics

\begin{tabular}{|l|l|l|l|l|l|l|}
\hline Case & Age/Sex & BMI & Tumor height & Tumor location & Resection margin & Histopathology \\
\hline Case A & $58 / \mathrm{F}$ & 24 & $15 \mathrm{~cm}$ & Anterior & Negative & $\begin{array}{l}\text { Tubular adenoma with low-grade } \\
\text { dysplasia }\end{array}$ \\
\hline Case B & $79 / \mathrm{F}$ & 24 & $7 \mathrm{~cm}$ & Posterior & Negative & Mod. dif. adenocarcinoma \\
\hline Case C & $71 / \mathrm{F}$ & 31 & $10 \mathrm{~cm}$ & Anterior & Negative & Tubulovillous adenoma \\
\hline Case D & $39 / \mathrm{M}$ & 23 & $6 \mathrm{~cm}$ & Anterior & Negative & Tubulovillous adenoma \\
\hline Case E & $34 / \mathrm{M}$ & 23 & $6 \mathrm{~cm}$ & Posterior & Negative & Deep cystic colitis \\
\hline
\end{tabular}

Abbreviations: F, female; M, male.

Table 2 Clinical and surgical results

\begin{tabular}{|l|l|l|l|l|l|}
\hline Case & Docking time & Surgery time & Surgery complications & LHS & Complications \\
\hline Case A & 6 minute & 195 minutes & Peritoneal access & 4 days & None \\
\hline Case B & 6 minute & 80 minutes & None & 24 hours & None \\
\hline Case C & 12 minute & 70 minutes & None & 24 hours & None \\
\hline Case D & 5 minute & 60 minutes & None & 24 hours & None \\
\hline Case E & 4 minute & 80 minutes & None & 24 hours & None \\
\hline
\end{tabular}

Abbreviation: LHS, length of hospital stay

The average surgery time was 85 minutes (60195 minutes) and average docking time was 6.6 minutes (4-12 minutes). As mentioned before, case A was a polyp at the rectosigmoid junction and required access to the peritoneal cavity to obtain free margins; besides, it was our first case, so it was the longest case of our series (195 minutes). Despite this, our mean average operative time was below of the reported for TEM (120-140 minutes) and similar to the mean reported time for TAMIS.

Differently from TAMIS, less torque is needed and less instrument collision is experienced in R-TAMIS; besides, there is no need for the help of an assistant holding the camera, there is significantly reduced loss of pneumorectum, thus providing a more stable intraluminal pressure and giving the surgeon a better view during the whole procedure.

\section{Discussion}

Total mesorectal excision was described by Dr. Buess et al. in $1983,{ }^{12}$ years before modern laparoscopic surgery had its peak in general as well as in colorectal surgery. However, despite the greatest advances in laparoscopic surgery over the past 20 years, the TEM technique has remained without change. Transanal minimally invasive surgery was described as a cost-effective alternative to this approach, as it offers minimum installation time, low-cost equipment, and instruments that are already available in most hospitals with laparoscopic surgery. Likewise, although initial experience proved its efficacy in the treatment of rectal neoplasia, this technique can be adapted and used for the surgical treatment of benign ano-rectal disease. ${ }^{5}$ 
Lirici et al. described this stage of rapid evolution of the minimally invasive surgery as the outburst era ${ }^{13}$, a time in which surgical innovation continues to be the foundation for the next generations of surgeons that are leading a step beyond conventional laparoscopic surgery. ${ }^{13,14}$

With all these advances in minimally invasive surgery and the great acceptance of TAMIS among colorectal surgeons and aiming to improve ergonomics and surgical technique, Atallah et al., in 2012, published the first performance of RTAMIS in a patient with a benign rectal neoplasia with excellent results. They described as the main advantages of the robotic platform a more comfortable and secure path for resection and closure of the defect within the rectal wall and the fact that the articulation of the robotic arms allowed better intraluminal dexterity; these benefits, added to the robotic 3D vision, significantly improved the surgeon's ability to perform the transanal resection of rectal lesions. ${ }^{15}$

Later, in 2014, Dr. Atallah et al. published a paper on the use of R-TAMIS for the resection of a malignant rectal neoplasia, corroborating the previously described benefits. ${ }^{14}$

Afterward and aiming to increase the evidence in favor of the use of a robotic platform for transanal resection, Dr. Atallah et al. published a case series of the first 18 cases on a cadaveric model. This series included benign as well as malignant rectal neoplasia, TME, and rectal fistulae, concluding that the use of R-TAMIS is feasible in almost any type of rectal lesion. However, they report that transanal surgery expertise is needed to obtain good results. ${ }^{11}$

The use of robotic platforms to perform R-TAMIS continued to expand, and, in 2018, Dr. Liu et al. published the first retrospective multi-institutional study of R-TAMIS in North America. They reported 34 cases, with a mean follow-up of 188 days and a distance from the anal verge between 2 and $15 \mathrm{~cm}$, with a mean operative time of $100+/-70$ minutes and a console time of $76+/-67$ minutes. They concluded that the use of a robotic platform increased the reach and the surgical movement range when compared with TAMIS and considered R-TAMIS as an efficient and safe alternative for low-risk rectal neoplasia excision. Also, they found that as body mass index (BMI) increased, so did surgical time and surgery complexity. ${ }^{16}$

In the present series, we present the initial experience of R-TAMIS in Mexico, which consists in our first five cases, all performed without any early or late postoperative complication and with surgery time within the limits of what is reported in the literature for this procedure.

As technological evolution outgrows older generations, the hope is that newer robotic platforms ( $\mathrm{Da}$ Vinci Xi) become the most utilized equipment in the world, and, with this, the advantages will directly reflect in lower operative and console time, due to easier use of the robotic platform.

The main limitations of our study are that it is a small series of patients (five cases) and that it is retrospective. However, as time passes and robotic surgery acceptance grows in our country, we hope to be able to expand our database and increase exponentially this initial experience.
In conclusion, this is a report of the initial experience of the use of transanal robotic surgery in Mexico for rectal neoplasia excision, which, according to our experience, can be successfully achieved in a wide variety of rectal lesions, up to $15 \mathrm{~cm}$ from the anal verge, and accomplish an adequate defect closure when the peritoneal cavity is accessed. Lesions above the peritoneal reflection require advanced transanal surgical skills, but excellent results can be achieved as well.

\section{Conflict of interests}

The authors have no conflict of interests to declare.

\section{References}

1 Tomassi MJ, Taller J, Yuhan R, Ruan JH, Klaristenfeld DD. Robotic Transanal Minimally Invasive Surgery for the Excision of Rectal Neoplasia: Clinical Experience With 58 Consecutive Patients. Dis Colon Rectum 2019;62(03):279-285

2 Izquierdo KM, Salem JF, Cha E, Unal E, Marks JH. Transanal Surgery: A History of taTME Ancestry. Clin Colon Rectal Surg 2020;33(03):128-133

3 Litynski GS. Profiles in laparoscopy: Mouret, Dubois, and Perissat: the laparoscopic breakthrough in Europe (1987-1988). JSLS 1999; 3(02):163-167

4 Rao GV, Reddy DN, Banerjee R. NOTES: human experience. Gastrointest Endosc Clin N Am 2008;18(02):361-370, x

5 Atallah S, Albert M, Larach S. Transanal minimally invasive surgery: a giant leap forward. Surg Endosc 2010;24(09):2200-2205

6 Atallah S, Albert M, deBeche-Adams T, Larach S. Transanal minimally invasive surgery (TAMIS): applications beyond local excision. Tech Coloproctol 2012

7 O'Neill CH, Platz J, Moore JS, Callas PW, Cataldo PA. Transanal endoscopic microsurgery for early rectal cáncer: a single-center experience. Dis Colon Rectum 2017;60(02):152-160

8 Clancy C, Burke JP, Albert MR, O'Connell PR, Winter DC. Transanal endoscopic microsurgery versus standard transanal excision for the removal of rectal neoplasms: a systematic review and metaanalysis. Dis Colon Rectum 2015;58(02):254-261

9 Hompes R, Rauh SM, Ris F, Tuynman JB, Mortensen NJ. Robotic transanal minimally invasive surgery for local excision of rectal neoplasms. Br J Surg 2014;101(05):578-581

10 Atallah SB, Albert MR, deBeche-Adams TH, Larach SW. Robotic transanal minimally invasive surgery in a cadaveric model. Tech Coloproctol 2011;15(04):461-464

11 Atallah S, Martin-Perez B, Parra-Davila E, et al. Robotic transanal surgery for local excision of rectal neoplasia, transanal total mesorectal excision, and repair of complex fistulae: clinical experience with the first 18 cases at a single institution. Tech Coloproctol 2015;19(07):401-410

12 Buess G, Theiss R, Günther M, Hutterer F, Pichlmaier H. [Transanal endoscopic microsurgery]. Leber Magen Darm 1985;15(06):271-279

13 Lirici MM, Kanehira E, Melzer A, Schurr MO. The outburst age: how TEM ignited the MIS revolution. Minim Invasive Ther Allied Technol 2014;23(01):1-4

14 Atallah S, Quinteros F, Martin-Perez B, Larach S. Robotic transanal surgery for local excision of rectal neoplasms. J Robot Surg 2014;8 (02):193-194

15 Atallah S, Parra-Davila E, DeBeche-Adams T, Albert M, Larach S. Excision of a rectal neoplasm using robotic transanal surgery (RTS): a description of the technique. Tech Coloproctol 2012;16 (05):389-392

16 Liu S, Suzuki T, Murray BW, et al. Robotic transanal minimally invasive surgery (TAMIS) with the newest robotic surgical platform: a multi-institutional North American experience. Surg Endosc 2019;33(02):543-548 